\title{
Impact of a Heutagogical, Multimedia-Based Teaching Concept \\ to Promote Self-Determined, Cooperative Student Learning in Clinical Radiology
}

\section{Wirkung eines heutagogischen, multimedialen Lehrkonzepts zur Förderung des selbstbestimmten und kooperativen Lernens von Medizinstudierenden in der klinischen Radiologie}

Authors

Ulf Teichgräber $^{10}$, Maja Ingwersen², Hans-Joachim Mentzel ${ }^{2}$, Rene Aschenbach², Rotraud Neumann², Tobias Franiel², Aimée Barbara Herzog ${ }^{2}$, Joachim Böttcher ${ }^{2}$, Alexander Pfeil ${ }^{3}$, Birger Mensel ${ }^{4}$, Christian Kühnel ${ }^{5}$, Martin Freesmeyer $^{5}$, Martin R. Fischer ${ }^{\circledR}$, Jan Zottmann ${ }^{6} \mathbb{}$

\section{Affiliations}

1 Department of Radiology, Friedrich Schiller University Jena, Germany

2 Department of Diagnostic and Interventional Radiology, Jena University Hospital, Jena, Germany

3 Department of Internal Medicine III, Jena University Hospital, Jena, Germany

4 Department of Diagnostic and Interventional Radiology and Neuroradiology, Central Hospital Bad Berka, Germany

5 Department of Nuclear Medicine, Jena University Hospital, Jena, Germany

6 Institute for Medical Education, University Hospital of LMU Munich, Munich, Germany

\section{Key words}

didactics, heutagogy, interactive learning environments,

key feature questions, flipped classroom, medical education

received 11.09.2020

accepted 11.11.2020

published online 16.12 .2020

\section{Bibliography}

Fortschr Röntgenstr 2021; 193: 701-711

DOI 10.1055/a-1313-7924

ISSN 1438-9029

(C) 2020. Thieme. All rights reserved.

Georg Thieme Verlag KG, Rüdigerstraße 14,

70469 Stuttgart, Germany

\section{Correspondence}

Prof. Dr. med. Ulf Teichgräber

Institut für Diagnostische und Interventionelle Radiologie,

Universitätsklinikum Jena, Friedrich-Schiller-University Jena,

Am Klinikum 1, 07747 Jena, Germany

Tel.: $+49 / 3641 / 9324831$

Fax: $+49 / 3641 / 9324832$

ulf.teichgraeber@med.uni-jena.de

\section{ZUSAMMENFASSUNG}

Ziel Die Vorlesung als Frontalunterricht ist ein zentraler Bestandteil der universitären Ausbildung. Allerdings sind hohe Kompetenzen zur Lösung von komplexen Aufgabenstellungen kaum durch einen überwiegend passiven Lernstiel zu erlangen. In dieser Studie haben wir das heutagogische Konzept des selbstbestimmten, integrierten Lernens in der radiologischen Hauptvorlesung implementiert und evaluiert.

Material und Methoden An der prospektiven Beobachtungsstudie nahmen 266 Medizinstudierende des vierten Studienjahres teil. Im Wintersemester 2019/2020 besuchten die Studierenden 11 Vorlesungen der klinischen Radiologie, die von 10 Dozierenden geleitet wurden. Die Studierenden wurden aufgefordert, sich mit Lernvideos auf jede der Vorlesungen gezielt vorzubereiten. Im Laufe der Vorlesung waren in Kleingruppen wiederholt „Key-Feature-Questions“ (KFQ) zu lösen und über ein Abstimmungssystem zu beantworten. Nach den Vorlesungen und der Schein-relevanten Abschlussprüfung wurden die Studierenden und Dozierenden zu ihrer Einschätzung des Konzepts befragt. Die Ergebnisse wurden mit einer historischen Kontrollgruppe verglichen.

Ergebnisse Der Gesamteindruck der Studierenden vom „flipped classroom"-Konzept sowie die Examensnoten waren besser als nach traditioneller Vorlesung (Gesamteindruck: 1,5 (95\%-KI 1,4-1,6) vs. 2,7 (95\%-KI 2,5-2,9) auf einer Skala von 1 bis 6; $p<0,001$; Examensnoten: 1,8 (95\%-KI 1,7-1,9) vs. 2,0 $(95 \%-K I ~ 1,9-2,0)$ auf einer Skala von 1 bis $5 ; p<0,001)$. Die meisten Studierenden bestätigten die Nützlichkeit der Lernvideos (76,6\%), der KFQ (88,5\%), des Abstimmungssystems (76,5\%) und der Gruppenarbeit (83,7\%). Die Dozierenden stellten eine bessere Übereinstimmung der Anforderungen an das Lernen mit späteren beruflichen Kompetenzen fest. Allerdings erforderte die Implementierung des neuen Konzepts einen nennenswerten Mehraufwand.

Schlussfolgerung Die Studierenden beurteilten den Gesamtnutzen des heutagogischen Lehrkonzepts „flipped classroom" in der klinischen Radiologie als hoch. Die Examensnoten verbesserten sich leicht gegenüber denen vergan- 
gener Jahrgänge mit traditioneller Vorlesung. Die Dozierenden äußerten, dass das „flipped classroom“-Konzept spätere berufliche Anforderungen gut repräsentiert.

\section{Kernaussagen:}

- Die Studierenden bewerteten den Nutzen des Konzeptes „flipped classroom“ als hoch.

- Die meisten Studierenden waren zufrieden mit den multimedialen und interaktiven Vorlesungselementen.

- Die Dozierenden beurteilten die Anforderungen selbstbestimmten Lernens als analog zur Berufspraxis.

\section{ABSTRACT}

Purpose To date, didactic lecturing is a common method of university medical training. However, higher levels of competence to solve complex issues are hardly to be achieved with a largely passive learning style. We established and evaluated a heutagogical blended learning concept to investigate selfdetermined learning with a multimedia-based, interactive approach in the lecture room to teach clinical radiology.

Materials and Methods In the 2019/2020 winter semester, we included 266 medical students in their fourth academic year in our prospective, observational study. Students participated in a series of 11 radiological lectures given by 10 lecturers. They were requested to prepare for lectures by watching learning videos. During the lecture, students had to answer key-feature questions (KFQ) in small groups and to jointly submit their answers by means of an audience response system (ARS). After each lecture and the exam, we conducted surveys and compared results with a historical control group. A focus group interview with lecturers was performed after conclusion of the lecture series.
Results The students' overall impression of the "flipped classroom" concept and their examination grades were superior to historical controls (overall impression: 1.5 [95\% Cl 1.41.6] vs. 2.7 [ $95 \% \mathrm{Cl} 2.5-2.9$ ] rated on a scale from 1 to 6 , $\mathrm{p}<0.001$; examination grades: 1.8 [95\% Cl 1.7-1.9] vs. 2.0 [95\% Cl 1.9-2.0] rated on a scale from 1 to $5, \mathrm{p}<0.001$ ). Most students agreed that learning videos (76.6\%), ARS (88.5\%), KFQ (76.5\%), and solution-oriented small group discussions (83.7\%) were useful. Lecturers stated an improved convergence of demands on learning and clinical competence. However, they also emphasized an increased initial effort for implementation.

Conclusion Students rated the overall benefit from the heutagogical "flipped classroom" concept as high. Examination grades improved. According to lecturers, the "flipped classroom" concept better matched later professional demands than traditional lectures.

\section{Key Points:}

- The benefit of the "flipped classroom" concept for radiological lectures was rated high by students.

- Most students were satisfied with the multimedia and interactive elements of lectures.

- Lecturers considered heutagogical learning demands as appropriate for later clinical requirements.

\section{Citation Format}

- Teichgräber U, Ingwersen M, Mentzel H et al. Impact of a Heutagogical, Multimedia-Based Teaching Concept to Promote Self-Determined, Cooperative Student Learning in Clinical Radiology. Fortschr Röntgenstr 2021; 193: 701711

\section{Introduction}

Over the past centuries, the main lecture series has been a cornerstone in German university education. The didactic lecture represents an integral part of the medical curriculum and is used for comprehensive factual knowledge transfer in each subspecialty. As a matter of fact, the traditional lecture format is still the dominant method of instruction in higher medical education, even though, it is a largely passive experience for many students. The possibility for students to interact with their lecturers is limited. The traditional lecture is characterized by passive learning, students receive information but do not otherwise engage with the learning content [1]. According to the revised cognitive Bloom's taxonomy of Anderson and Krathwohl, the traditional lecture can be classified hierarchically in a lower cognitive domain of "remembering" and "understanding" ( $\triangleright$ Fig. 1) [2, 3]. Thus, a higher level of competence such as "applying" and "analyzing" remains unattainable with the lecture methodology since its main purpose is the transfer of factual knowledge. The only active task students undertake during a lecture is to take notes. Nevertheless, in radiology the didactic concept of traditional lecture series is characterized by motivated lecturers to demonstrate the latest imaging technologies with the endeavor to give students a comprehensive overview of state-of-the-art radiological imaging. Surprisingly, a review of the last decade showed that only an average of one fifth of students were regularly attending the compulsory lecture series in radiology and nuclear medicine. In fact, for exam preparation, students use online scripts and copies of lecture slides, and thus skip the actual lecture.

We as lecturers felt that the traditional lecture concept needed to be improved to make learning more attractive and to facilitate a higher level of competence. With the introduction of the blended learning (BL) concept referred to as the "flipped classroom", combining multimedia-based and cooperative elements, we intended to promote a heutagogical didactic approach. Heutagogy refers to a self-determined learning concept that promotes autonomy, capacity, and capability of students [4, 5].

In this study, we aimed to investigate whether a "flipped classroom" radiology lecture leads to markedly improved acceptance and subjective learning progress in medical students and whether medical teachers endorse the new lecture concept with regard to efforts and benefits as compared to the traditional lecture. 


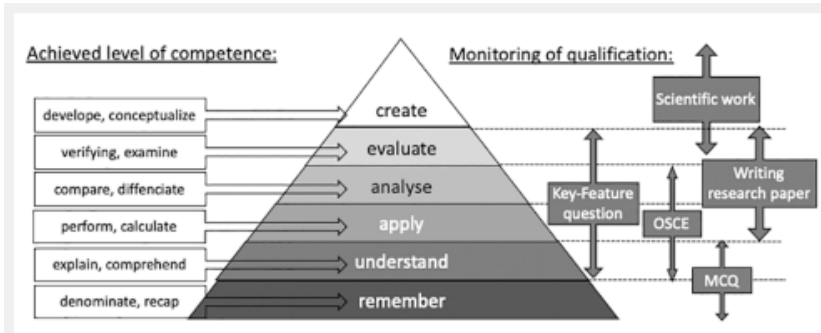

- Fig. 1 Bloom's Taxonomy for educational objectives (adapted from Bloom, 1956 [1]; Anderson \& Krathwohl, 2001 [2]) demonstrating the level of competence with corresponding options of examination methodologies. MCQ = multiple choice question; $\mathrm{OSCE}=$ objective structured clinical examination .

- Abb. 1 Blooms Taxonomie der Lernziele (nach Bloom 1956 [1] und Anderson \& Krathwohl, 2001 [2]). Gezeigt werden die Ebenen der Kompetenzen mit ihren korrespondierenden Messmethoden. MCQ = Multiple-choice-Fragen; OSCE = objective structured clinical examination.

\section{Materials and Methods}

\section{Study Design}

A non-randomized prospective observational study was conducted to evaluate the introduction of an innovative $\mathrm{BL}$ concept referred to as the "flipped classroom" for radiology lectures to increase cooperative learning. The novel BL concept was compared to a historical control group of traditional lectures from previous years. Our project represents a pilot test and evaluation of a complex educational setting that applies different didactic elements conducted in a real-world setting. We hypothesized that student satisfaction with the "flipped classroom" concept would be superior to the satisfaction of a historical control group with traditional lectures.

Ethical approval for the evaluation protocol of this study was obtained from the local ethics committee. All survey data from the study cohort and historical control was analyzed anonymously.

\section{Heutagogical, interactive "flipped classroom" lecture concept}

The novel "flipped classroom" radiological lecture series was introduced for the first time in the winter semester 2019/20 to a full cohort of fourth-year medical students $(n=266)$. A completely new lecture concept was introduced. Beforehand, all students were informed via online podcast about the heutagogical concept including the obligatory preparation with learning videos and the new process in the lecture hall. Ten medical teachers (hereinafter referred to as lecturers) participated in the 11 lectures. All of them were board-certified radiologists, who had experience giving lectures and had participated in the traditional lecture series in previous years. Each of the nine radiologists and one nuclear medicine physician gave a lecture on their subspecialized area of expertise.

The lecturers received training on the didactic concept regarding how to define intended learning outcomes (ILO), and how to pre-

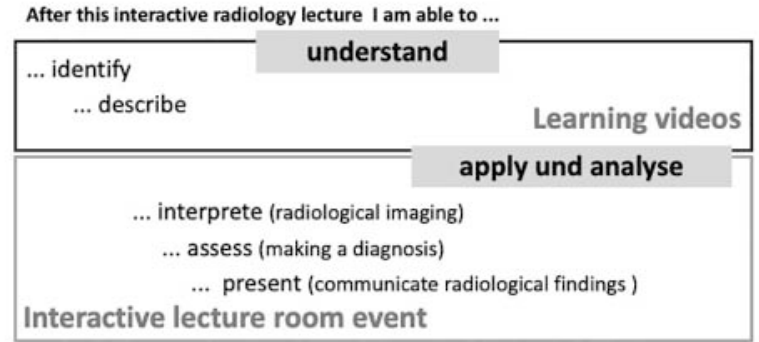

- Fig. 2 Structure of learning objectives following the "What's in it for me" (WIIFM) principle from the student perspective. Differentiating two cognitive levels of understanding by learning videos and application/analysis by the interactive lecture with attendance of the students in the lecture hall.

- Abb. 2 Struktur der Lernziele „What's in it for me“ (WIIFM-Prinzip) aus Sicht des Studierenden. Es werden die 2 kognitiven Ebenen des Verstehens mithilfe von Lernvideos und der Anwendung/Analyse durch Teilnahme an interaktiven Vorlesungen dargestellt.

pare learning videos. They received a roadmap to design the attending phase for their lecture. The lecturers conducted their lectures with support of an assisting lecturer in the lecture hall. To define and translate the ILOs to the students, it was important to identify their needs, attract their interest, and meet their expectations regarding the lecture series [6]. ILOs were given to the students following the WIIFM principle (acronym: What's in it for me?) looking through the eyes of students by using first-person perspective rather than looking at the lecture content from the perspective of the teacher ( $\triangleright$ Fig. 2) [7]. ILOs were forwarded with the learning videos and additionally communicated during the interactive lecture in the lecture hall as well as on the worksheets.

The "flipped classroom" can be considered as a special type of $B L$ that reverses the traditional learning environment in which a self-directed learning phase (online videos for conceptual knowledge transfer) takes place before the classroom attending phase (procedural knowledge transfer) to explore topics in greater depth, to impart skills, and to create meaningful learning opportunities [8]. The flipped classroom concept is best described by heutagogical learning, otherwise known as self-determined learning. In a heutagogical approach of teaching and learning, learners are highly autonomous and self-determined. Emphasis is placed on the development of learner capacity and capability with the goal of producing learners who are well-prepared for the complexities of today's workplace [9].

The "flipped classroom" concept was applied as an active learning model, in which students first learn content at home by video lectures (preparation phase), and thereafter discuss and solve problems within the class (attendance phase) [10]. The participating lecturers were asked to prepare a short online learning video on their specific lecture topic. The specification of an ideal length for the video lesson was eight to twelve minutes [11]. The videos focused only on one component of the lecture topic (radiology subspecialty) with the specific intention of preparing the students for the interactive attendance phase in the lecture hall. 


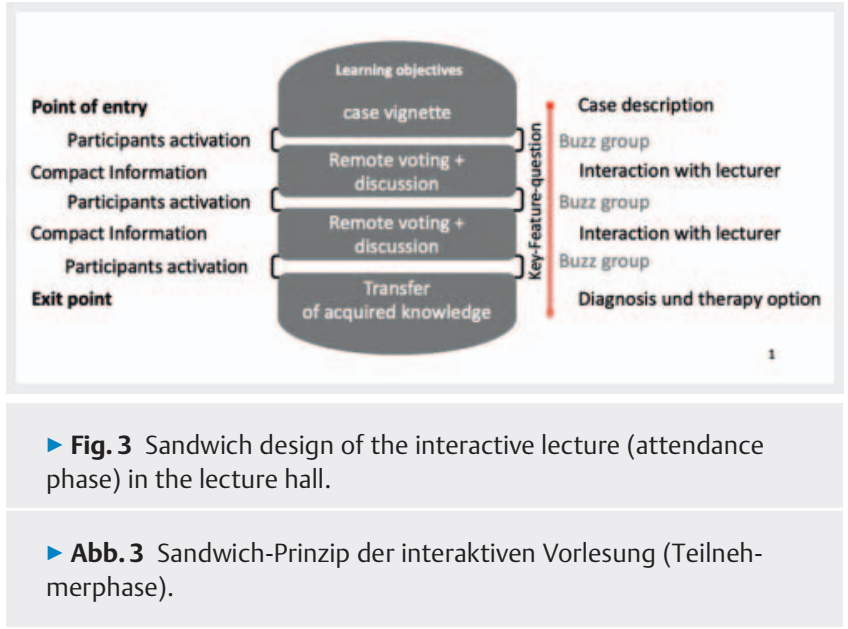

Students were asked to watch the online learning videos and prepare themselves with additional resources. A timeframe of at least 45 minutes was recommended for preparation.

Instead of using the attendance phase for factual knowledge transfer, it was transformed into an interactive and collaborative learning experience. A so-called sandwich design was integrated to recall learned knowledge and to increase the students' attention span during the lecture [12]. The sandwich design contains different alternating didactic methods which reinforced themselves ( $\triangleright$ Fig. 3 ). In the attendance phase, key-feature questions (KFQs) represented the backbone of the sandwich design. The KFQs were written on worksheets which were handed out to the students at the beginning of the lecture. A short case description (eyecatcher function) represented the entry point.

Each lecture contained one specific case description followed by 3 to 5 key features which had to be solved in buzz groups by the students during the lecture. The use of buzz groups represents a main procedure step of the interactive lecture concept to encourage cooperative learning with active participation of individual students during the lecture [13]. Buzz groups were formed by dividing the large group of students in the lecture hall into small discussion groups of 2 to 3 students who meet simultaneously for a specified time to discuss a specific question (collaborative phase) [14]. Buzz groups were formed by students who were sitting next to each other in a row of the lecture hall. Each buzz group received a worksheet and a televoting "clicker" for the audience response system (ARS; synonym for TED = Technology, Entertainment, Design) (Turning Technologies, Youngstown, Ohio, USA). The individual votes of the KFQs of each buzz group were entered into an online clicker. The anonymized analyses of all votes were displayed immediately on the screen of the lecture hall [15]. The results of the buzz group votes on each KFQ were discussed interactively between students and the lecturer (interactive phase). According to the sandwich design, this alternation between cooperative and interactive phases was repeated until all KFQs had been answered and discussed. As the exit point of the interactive lecture after solving the KFQs, a transfer to the diagnosis and treatment options was summarized by the lecturer at the end of the interactive lecture.

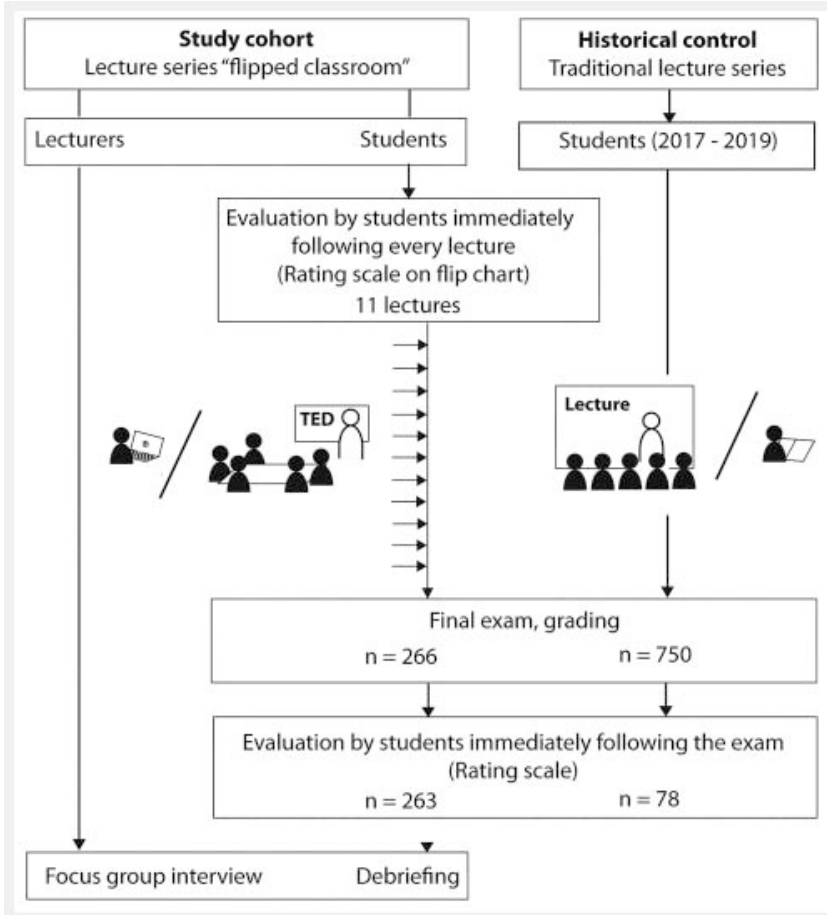

- Fig. 4 Evaluation flowchart. KFQ = key feature question.

Abb. 4 Flussdiagramm der Evaluation. KFQ = key feature question.

In contrast, traditional radiology lectures had been given from the front of the lecture hall using PowerPoint presentations with printed versions of slides that were accessible online for exam preparation. Knowledge and understanding of state-of-the-art technologies had been imparted mainly by means of clinical cases. Lecturers for the historical control group were largely the same as for the study cohort. Lecture topics were the same as in the novel "flipped classroom" concept. However, no ILOs were defined. Except for an obligatory 90 -minute seminar concerning general radiology, dialog between the lecturer and students as well as a professional exchange among students was rare in the historical control.

\section{Surveys and outcomes}

The study cohort participated in the interactive "flipped classroom" lecture series, whereas the historical control group underwent previous years of traditional lecture series representing the classic lecture style ( $\triangleright$ Fig. 4 ). Both study groups with all participating fourth-year medical students had to undergo a multiplechoice (MC) examination at the end of the lecture series. Students were asked to voluntarily complete a quantitative paper questionnaire with a 6-point rating scale (with 1 representing the highest, and 6 the lowest level of satisfaction) of seven questions on specific quality and process issues. This questionnaire also offered a section for free-response "further comments" after the radiology exam. The end-of-semester exam as well as the questions on the students' survey remained identical to the previous years to allow 
- Table 1 Results of a survey of medical students regarding the "flipped classroom" blended learning concept after the radiology exam.

- Tab. 1 Ergebnisse einer Befragung der Studierenden zum Konzept des integrierten Lernens „flipped classroom“ nach dem Examen.

\begin{tabular}{|c|c|c|}
\hline positive aspects & negative aspects & suggestions for improvement \\
\hline - videos brief and concise & - video monotonous, unstructured & - E-mail notification as a reminder \\
\hline - practical exercises, case conferences & - too many slides & - add pictures to key feature questionnaires \\
\hline - motivated by involvement of lecturers & - uncertainty regarding learning objectives & - follow the style of official exam questions \\
\hline - interactive collaboration & $\begin{array}{l}\text { " uncertainty regarding relevance with } \\
\text { respect to the final exam }\end{array}$ & $\begin{array}{l}\text { - provide access to learning materials and } \\
\text { key feature questions on a single online } \\
\text { platform }\end{array}$ \\
\hline - allowed to learn at one's own pace & - lecture time not fully exploited & $\begin{array}{l}\text { - provide a combination of traditional and } \\
\text { "flipped classroom" lectures }\end{array}$ \\
\hline - fun while learning & - some case studies were too difficult & - training of systematic diagnostics \\
\hline $\begin{array}{l}\text { - lecturers made every effort to teach } \\
\text { students }\end{array}$ & & $\begin{array}{l}\text { - explanation of right/wrong answers to the } \\
\text { televoting (ARS) }\end{array}$ \\
\hline
\end{tabular}

a direct comparison of students' achieved grades, given evaluations, and reported experiences.

An additional voluntary student assessment was offered to the study cohort following each BL "flipped classroom" lecture. Specifically, students were asked to assess learning videos, ARS, interactive exercises, and buzz group activities. The survey consisted of a 3-point bipolar Likert scale (agree, neutral, disagree) for four questions immediately after each of the 11 topics of the lecture series. Moreover, students were asked to report their overall impression of each lecture topic on a $0-10$ rating scale $(0=$ not satisfied, 10 = extremely satisfied) immediately after the lecture.

Apart from this, after the end of the semester, a survey of the medical teachers was conducted by means of a focus group interview to evaluate their perception of the interactive "flipped classroom" concept. All lecturers were invited to participate in a moderated group discussion to report on their experience with the new lecture format [16]. According to an interview manual, seven questions were asked. In detail, the questions related to the general impression of "flipped classroom" lectures, the main impact of the concept, effort needed, ARS, buzz groups, change compared with traditional lectures, and student satisfaction. These questions were outlined on a pinboard by the moderator. Applying a metaplan technique, lecturers were asked to write down their valuations and ideas on cards and to pin them to the board. In the further evaluation process, the lecturers' cards were sorted and summarized in an affinity diagram [17].

\section{Statistics}

Categorical variables are given as counts and percentages and continuous variables as means and standard deviations (SD). Differences were assessed with Mann-Whitney $U$ or chi-squared tests. Results are presented as parameter estimates and their corresponding $95 \%$ confidence intervals $(\mathrm{Cl})$. A two-sided value of $\mathrm{p}<0.05$ was considered statistically significant. Analysis was performed using XLSTAT (Version 2015.6.01.24 026, Addinsoft, Paris, France).

\section{Results}

In the voluntary end-of-semester student survey, $254 \pm 4.7$ students of the "flipped classroom" lecture (winter semester 2019/20) and $77 \pm 0.9$ students of the previous years' traditional lecture (winter semesters 2017-2019) answered the standardized questionnaire. The survey response rate of the "flipped classroom" lecture group was $95.6 \%$ as compared to $28.8 \%$ in the traditional lecture group. The overall impression was rated with an average school grade of 1.5 (good) in the "flipped classroom group" and with 2.7 (satisfactory) in the traditional lecture group $(p<0.001)$. The detailed survey results are shown in $\mathbf{F i g . 5 a}$. The students' examination grades were slightly but significantly better $(1.8$ [95\% Cl: $1.7-1.9])$ in the "flipped classroom" group as compared to the traditional lecture group (2.0 [95\% Cl: 1.9-2.0]; p<0.001) ( $\mathbf{F i g . 5 b ) . ~ A ~ s u m m a r y ~ o f ~}$ the students' survey results regarding their learning experience with the interactive lecture is shown in $>$ Table 1.

The students' assessment of the different topics of the lecture series demonstrated that students broadly agreed that learning videos were helpful for preparation of the individual lecture topics in 8 out of 11 videos. Students were dissatisfied with the learning videos only for gynecological radiology, prostate MRI, and pediatric radiology. For all lecture topics, students agreed that the ARS was a useful learning tool, that they gained additional insight through the interactive lecture experience, and that the buzz groups were helpful for them ( $\triangleright$ Fig. 6 ).

Students reported an individual overall impression of the lecture series which was extremely or very satisfied for 8 out of 11 topics. Even with the remaining 3 topics (gynecological imaging, prostate MRI, and pediatric radiology), students were still satisfied ( $\triangleright$ Fig. 7). A comparison of surveys demonstrated a significantly better overall impression of the lecture series after the examination at the end of the semester as compared to a summary of the individual surveys right after each lecture with respect to learning videos, additional insights, and buzz group experience $(p<0.01)$. The overall usefulness of the ARS was rated equivalent 


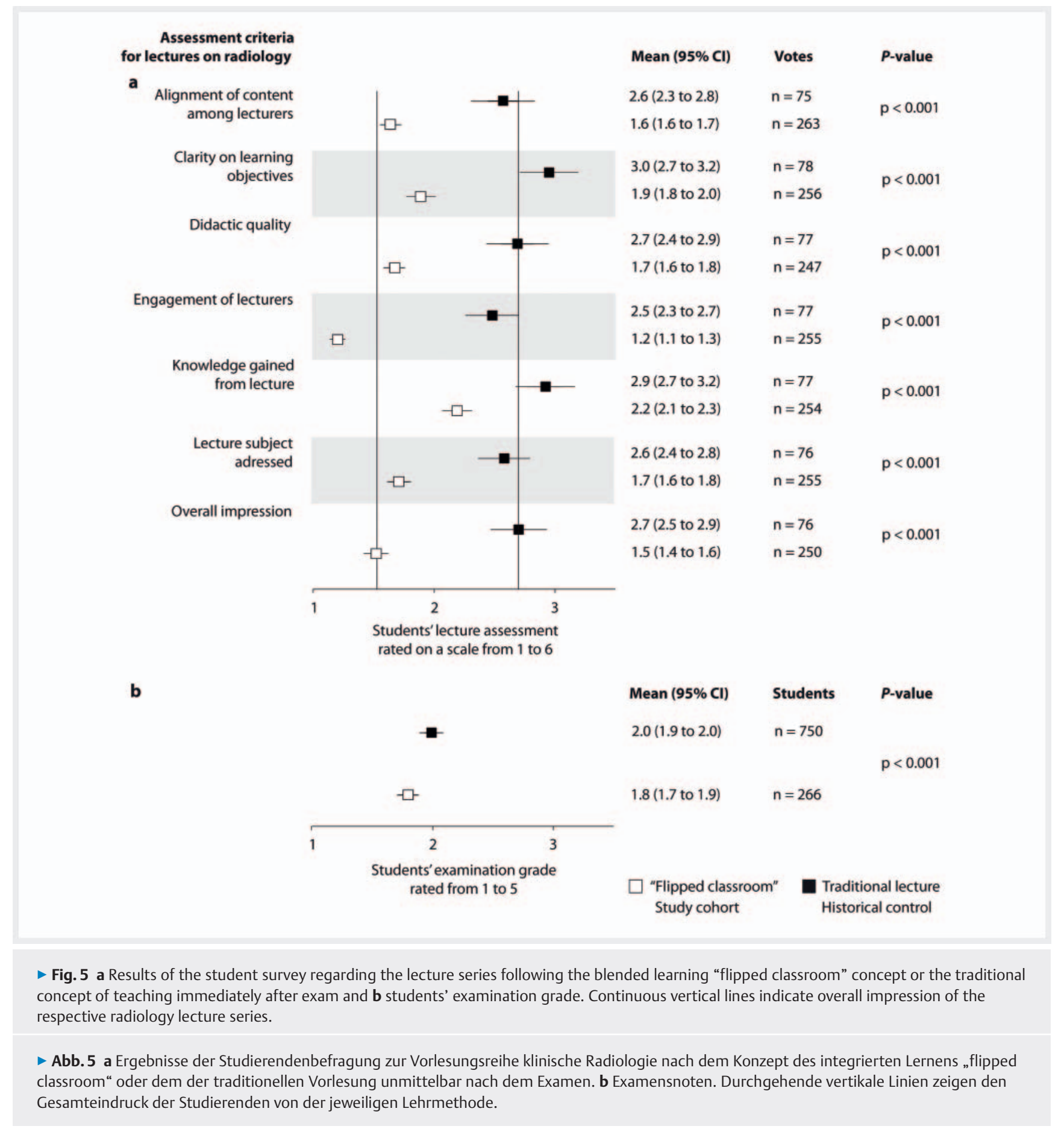

after the lecture and the examination at the end of the semester ( $\vee$ Fig. 8).

In the focus group interview, medical teachers endorsed the flat hierarchy. The role of the medical teacher has changed from traditional lecturer as knowledge mediator to moderator. They also stated that the interactive lecture meets students' needs and attracts their attention. However, the medical teachers complained that this new interactive lecture concept required significant initial preparation effort. In addition, there seems to be a lack of coverage of the entire radiology curriculum as compared to the traditional lecture concept. The summarized focus group interview with the lecturers is shown in $\boldsymbol{\nabla}$ Table 2 .

\section{Discussion}

The heutagogical BL concept of teaching was implemented and tested under real-world conditions with a full cohort of fourthyear medical students applying a design-based research approach [18-21]. The central goal was to enable interactive and cooperative learning in the lecture room. Chi et al. proposed an engage- 


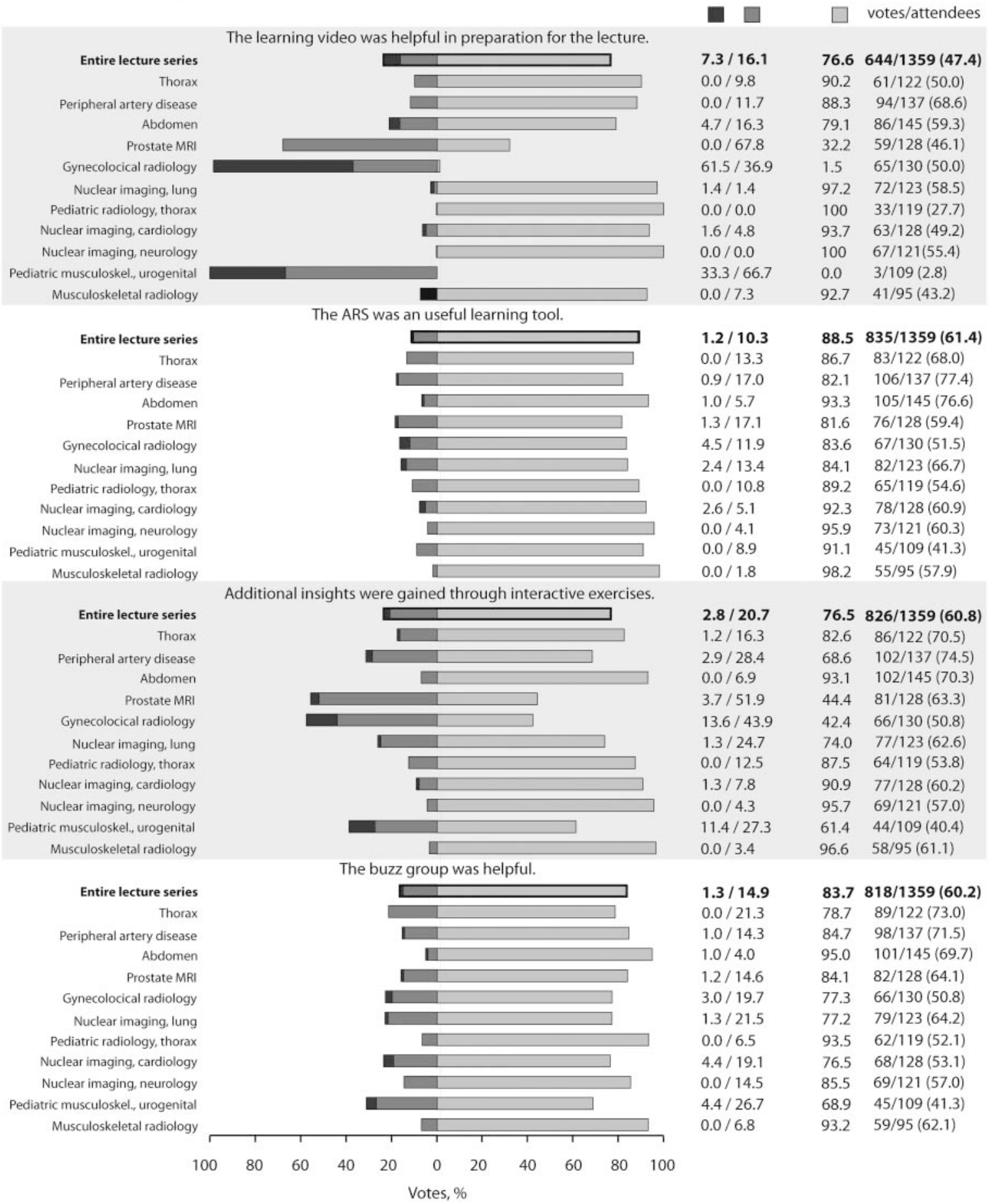

- Fig. 6 Students' assessment of every lecture following the blended learning "flipped classroom" concept on a 3-point bipolar Likert scale immediately after the lecture. ARS = audience response system.

- Abb. 6 Studentische Beurteilung unmittelbar im Anschluss an die Vorlesung nach dem Konzept „flipped classroom“ auf einer 3-stufigen bipolaren Likert-Skala. ARS = Abstimmungssystem.

ment behavior of students that outlines four levels of activity, predicting that as students become more engaged with the learning content, from passive to active to constructive to interactive, the learning effect will increase (ICAP framework) [22]. The advantage of our approach is that we go far beyond the factual knowledge transfer of a traditional lecture because an interactive 


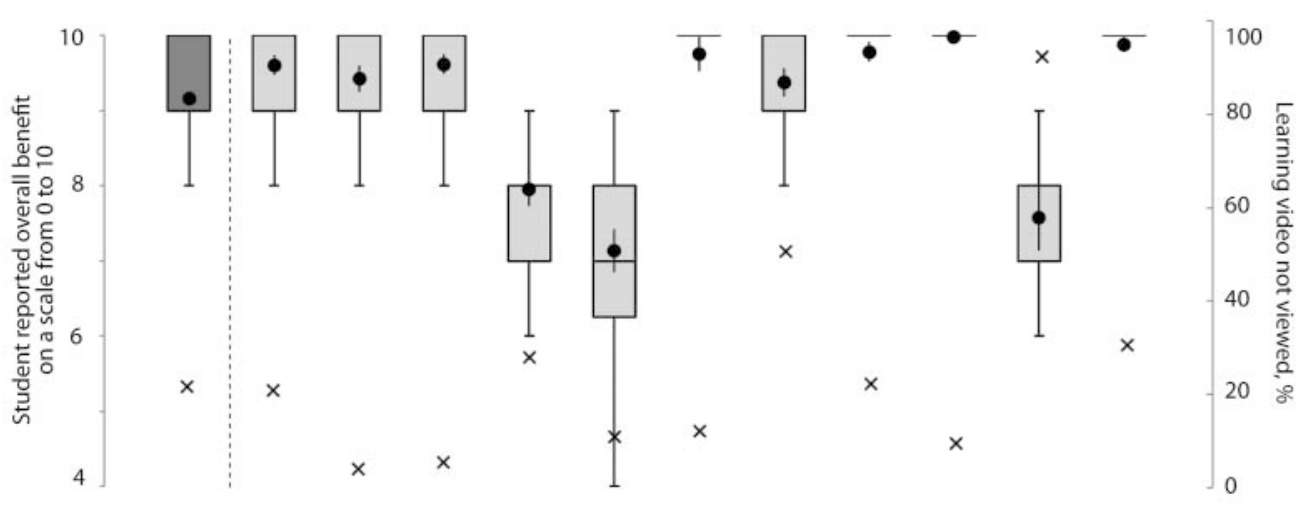

\begin{tabular}{|c|c|c|c|c|c|c|c|c|c|c|c|c|}
\hline \multicolumn{13}{|c|}{ Student reported benefit } \\
\hline Mean & 9.2 & 9.6 & 9.4 & 9.6 & 8.0 & 7.1 & 9.8 & 9.4 & 9.8 & 10.0 & 7.6 & 9.9 \\
\hline SD & 1.3 & 0.6 & 0.9 & 0.7 & 1.0 & 1.3 & 1.0 & 0.8 & 0.6 & 0.2 & 1.3 & 0.4 \\
\hline \multicolumn{13}{|c|}{ Studends who did not watch the learning video } \\
\hline$\%$ & 21.7 & 20.8 & 4.1 & 5.5 & 28.0 & 11.0 & 12.2 & 50.7 & 22.2 & 9.5 & 92.3 & 30.5 \\
\hline & 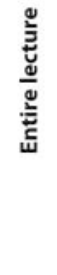 & 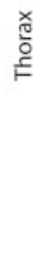 & 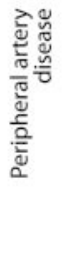 & $\begin{array}{l}\text { वे } \\
\text { है } \\
\frac{0}{0} \\
\frac{0}{<}\end{array}$ & 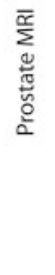 & 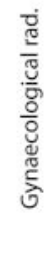 & 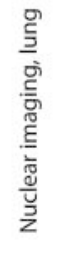 & 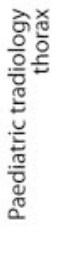 & 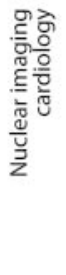 & 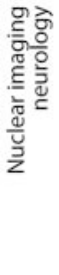 & 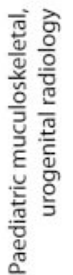 & 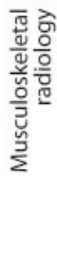 \\
\hline
\end{tabular}

- Fig. 7 Student-reported overall impression of the lecture series following the blended learning "flipped classroom" concept on a rating scale of 0 to $10(0=$ not satisfied, $10=$ extremely satisfied $)$ immediately after the lecture. Box plots indicate median and interquartile range. Whiskers end with the lowest and highest data point within $1.5 \times$ interquartile range. Dots represent means with their corresponding $95 \%$ confidence interval. Crosses indicate the proportion of students who did not watch the learning video.

- Abb.7 Gesamteindruck der Studierenden von der Vorlesungsreihe nach dem Konzept des integrierten Lernens „flipped classroom“ unmittelbar nach der Vorlesung auf einer Skala von 0 bis $10(0=$ nicht zufrieden, $10=$ sehr zufrieden). Box-Plots zeigen Median und Interquartilsabstand. Die Enden der Whisker markieren die höchsten und niedrigsten Werte innerhalb des 1,5-fachen Interquartilsabstands. Die Punkte zeigen die Mittelwerte mit ihren 95 \%-Konfidenzintervallen. Kreuze zeigen den Anteil der Studierenden, die das Lernvideo nicht angeschaut haben.

lecture concept enables a learning experience in a higher cognitive domain. The students perform lower levels of cognitive work (gaining knowledge and comprehension) outside the class (learning videos) and focus on the higher levels of cognitive work (application, analysis, synthesis, and evaluation) in class during the lecture (attendance phase), where they have the support of their peers and lecturers.

The students are guided interactively to discuss KFQs in small buzz groups. Each buzz group needs to agree on exactly one answer, meaning that there must be a phase of knowledge activation and discussion before an agreed-upon common response was entered on the clicker. This process strongly supports interaction of students in the large lecture hall by having them work cooperatively together in a predetermined time frame. Following the sandwich design, these interactive phases in the buzz groups took place repeatedly to solve the KFQs. The buzz group sets the groundwork to get the discussion started. Buzz groups motivate and activate students to learn [23]. In combination with ARS, it also opens the door to new question types including radiological images and text answers. Premkumar et al. have shown that ARS can support active learning and meaningful rapid feedback to answers to KFQ responses. This is certainly the main reason why the ARS was highly appreciated by the students and received the highest grades of all voting items in the evaluation [24]. However, ARS itself does not improve learning. It just opens the door to the use of didactic strategies that were previously not possible in a lecture hall with a large number of students. Therefore, ARS can be considered an exciting addition to the lecturer's toolbox [15].

During the buzz group phase, the level of noise increased tremendously with about 50 buzz groups working in parallel cooperatively in the lecture hall. The lecturer serves as moderator and is available for questions and for discussion of the KFQ results after ARS votes. KFQs ought to test clinical decision-making skills. They are based on the concept of critical steps or 'key features' in decision-making and represent a reliable patient management problem format [25]. Fischer et al. have demonstrated that electronic KFQs can be applied as feasible and reliable evaluation tools that may be implemented for the assessment of clinical undergraduate training [26]. Conceptual knowledge is known to be an essential prerequisite for clinical problem solving which has been conveyed by learning videos in the preparation phase, whereas KFQs concentrate on procedural knowledge transfer to foster clin- 


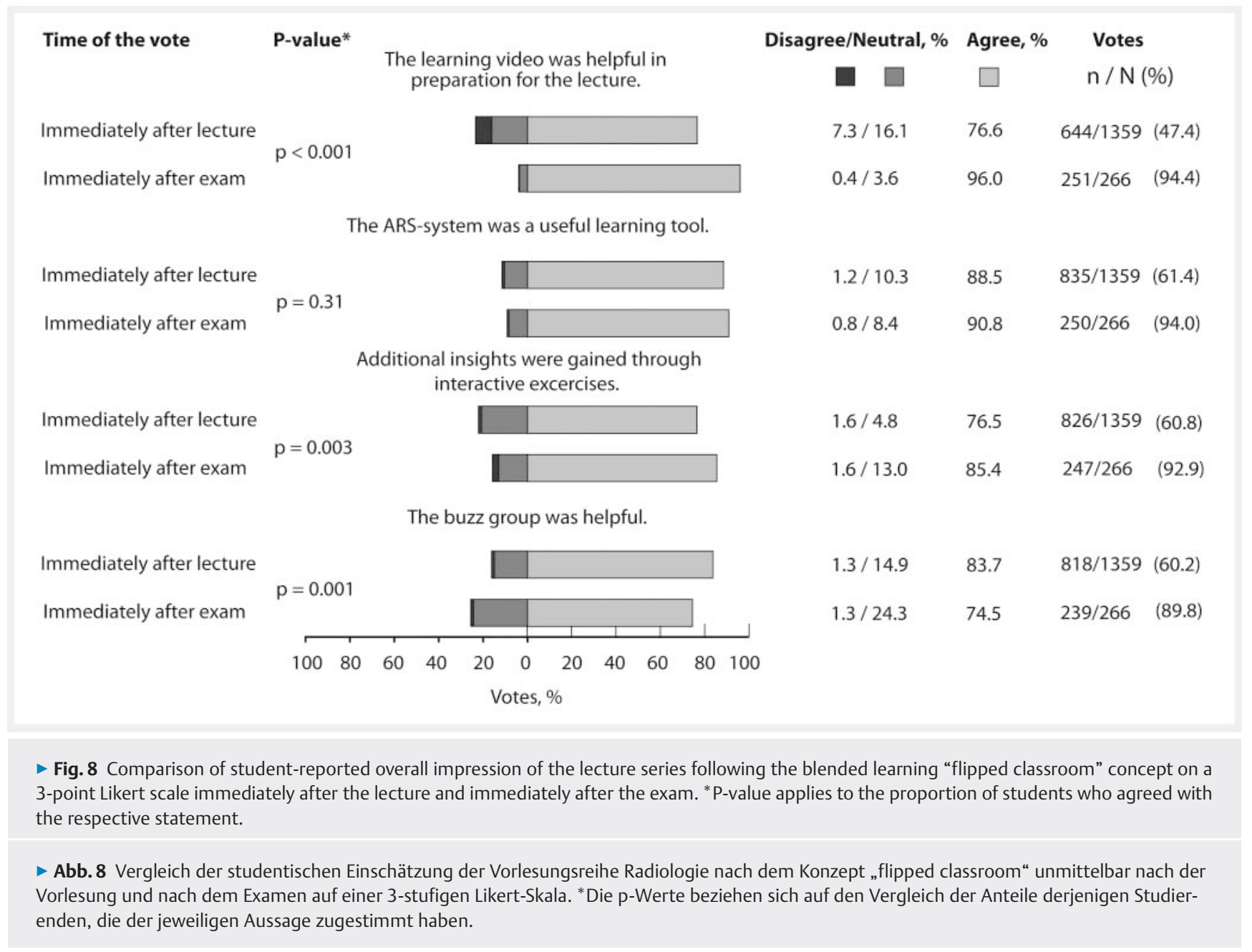

ical experience and clinical problem solving [27]. In the focus group interview, lecturers positively commented on how KFQs motivate and increase students' attention and thus prepare students for clinical activities.

BL combines traditional face-to-face learning and asynchronous or synchronous e-learning [28], thereby providing the basis of our interactive lecture concept. The flipped classroom intentionally shifts instruction to a heutagogical learner-centered model. Teacher interaction with students is more personalized - with guidance instead of lecturing. Bergmann et al. defined the flipped classroom concept as a framework that ensures that students receive a personalized education, tailored to their individual needs [29]. We introduced online learning videos to replace the conceptional knowledge transfer which was done before in a traditional lecture as a place-based method.

Our study has some limitations. Evidence of comparative results is low because we did not conduct a randomized comparison to traditional lectures. The historical control consisted of students who attended one of the previous three winter semesters and participation of these students in the survey was low. Furthermore, the students' assessment of benefit from the lecture is highly subjective and might not reflect gained skills and sustainability with certainty. Even exam grades do not necessarily predict subsequent professional skills. Finally, student satisfaction might have been associated with the lecturers' increased motivation in "flipped classroom" lectures due to their greater involvement in didactic preparation.

\section{Conclusion}

We implemented and evaluated the heutagogical, multimediabased "flipped classroom" learning concept in radiology lectures for fourth-year medical students to promote self-determined and cooperative competencies. The students' overall impression of the "flipped classroom" concept including the categories of content, clarity, didactic quality, lecturers' involvement, and gain of knowledge was superior to that of traditional lectures as rated by a historical control group. Lecturers noted a better match of achieved competencies with later professional requirements.

Implementation of the "flipped classroom" concept involves considerable effort on the part of lecturers. 
- Table 2 Focus group interview with lecturers regarding the "flipped classroom" blended learning concept after conclusion of the lecture series.

- Tab.2 Fokusgruppen-Interview mit den Dozierenden zum Konzept des integrierten Lernens „flipped classroom“ nach Abschluss der Vorlesungsreihe.

\begin{tabular}{|c|c|c|}
\hline questions & positive aspects & negative aspects \\
\hline $\begin{array}{l}\text { please give your general impression of the } \\
\text { "flipped classroom" concept. }\end{array}$ & $\begin{array}{l}\text { - meets students' needs } \\
\text { - increased interaction between students } \\
\text { - students had fun while learning }\end{array}$ & - significant initial effort \\
\hline $\begin{array}{l}\text { what was the main impact of the "flipped } \\
\text { classroom" concept? }\end{array}$ & $\begin{array}{l}\text { - stepwise acquisition of knowledge } \\
\text { " matches clinical issues } \\
\text { " practical application of selected skills } \\
\text { " attracts students' attention } \\
\text { - encourages independent planning and } \\
\text { structured approach }\end{array}$ & $\begin{array}{l}\text { - lack of completeness } \\
\text { - legal certainty? } \\
\text { - requires students to be responsible } \\
\text { for themselves }\end{array}$ \\
\hline $\begin{array}{l}\text { how much effort was needed for preparation } \\
\text { and implementation? }\end{array}$ & - hereafter, equal to traditional lectures & $\begin{array}{l}\text { - increased initial effort } \\
\text { - copyright issues with illustrations }\end{array}$ \\
\hline $\begin{array}{l}\text { how do you assess key feature questionnaire by } \\
\text { audience response system (ARS)? }\end{array}$ & $\begin{array}{l}\text { - prepares for exam } \\
\text { - prepares for clinical activities } \\
\text { - increases attention } \\
\text { - active part of students } \\
\text { - motivates students } \\
\text { - increases learning effect }\end{array}$ & - adverse effect on exam preparation \\
\hline $\begin{array}{l}\text { how would you assess students' group work and } \\
\text { buzz groups? }\end{array}$ & $\begin{array}{l}\text { - intensive exchange within groups } \\
\text { - deepens insight } \\
\text { - matches clinical work routine } \\
\text { - increases understanding } \\
\text { - encourages teamwork }\end{array}$ & - introduce time limit (timer) \\
\hline $\begin{array}{l}\text { how would you assess students' group work and } \\
\text { buzz groups? }\end{array}$ & $\begin{array}{l}\text { - intensive exchange within groups } \\
\text { - deepens insight } \\
\text { - matches clinical work routine } \\
\text { - increases understanding } \\
\text { - Encourages teamwork }\end{array}$ & - introduce time limit (timer) \\
\hline $\begin{array}{l}\text { what has changed regarding your role as a } \\
\text { lecturer? } \\
\text { how do you assess spatial conditions? }\end{array}$ & $\begin{array}{l}\text { - from knowledge mediator to moderator } \\
\text { - increased interaction with students } \\
\text { - "integrated" teacher } \\
\text { - flat hierarchy } \\
\text { - can be realized with up to } 200 \text { students }\end{array}$ & \\
\hline $\begin{array}{l}\text { do you think the students were satisfied and } \\
\text { learned more than with traditional lectures? } \\
\text { (effect on attendance?) }\end{array}$ & $\begin{array}{l}\text { - greater student satisfaction } \\
\text { - sustainable knowledge } \\
\text { - attendance similar or better }\end{array}$ & " selective gain of knowledge \\
\hline
\end{tabular}

\section{CLINICAL RELEVANCE OF THE STUDY}

- The "flipped classroom" model following the concept of blended learning supported greater student activity compared to traditional lectures.

- Heutagogical teaching conveys higher levels of competence such as interpretation of radiological images, diagnosis, and communication of radiological findings.

- Promotion of self-determined, cooperative student learning improves subsequently required professional skills in clinical radiology.
Conflict of Interest

The authors declare that they have no conflict of interest.

\section{References}

[1] Chimmalgi M. Interactive Lecture in the Dissection Hall: Transforming Passive Lecture into a Dynamic Learning Experience. Anat Sci Educ 2019; 12: 191-199

[2] Bloom BS. Taxonomy of Educational Objectives, Handbook: The Cognitive Domain. New York: David McKay; 1956

[3] Anderson LW, Krathwohl DR. A taxonomy for learning, teaching, and assessing: A revision of Bloom's Taxonomy of Educational Objectives. New York: Longman; 2001 
[4] Abraham RR, Komattil R. Heutagogic approach to developing capable learners. Med Teach 2017; 39: 295-299

[5] Links M]. Beyond competency-based continuing professional development. Med Teach 2018; 40: 253-258

[6] Biggs ], Tang C. Teaching for Quality Learning at University. 4. ed. Open University Press; 2011

[7] Goudreau KA. LACE, APRN consensus... and WIIFM (What's in it for me)? Clin Nurse Spec 2011; 25: 5-7

[8] Tolks D, Schafer C, Raupach T et al. An Introduction to the Inverted/ Flipped Classroom Model in Education and Advanced Training in Medicine and in the Healthcare Professions. GMS J Med Educ 2016; 33: Doc46

[9] Canning N, Callan S. Heutagogy: Spirals of reflection to empower learners in higher education. International Review of Research in Open and Distance Learning 2012; 11: 71-82

[10] French H, Arias-Shah A, Gisondo C et al. Perspectives: The Flipped Classroom in Graduate Medical Education. Neoreviews 2020; 21: e150-e156

[11] Ronchetti M. Using Video Lectures to Make Teaching More Interactive. International Journal of Emerging Technologies in Learning (iJET) 2010; 5: $45-48$

[12] Kadmon M, Strittmatter-Haubold V, Greifeneder R et al. [The sandwich principle - introduction to learner-centred teaching/learning methods in medicine]. Z Evid Fortbild Qual Gesundhwes 2008; 102: 628-633

[13] Cooling NJ, Li JT. A novel perspective on medical education. Med Teach 1991; 13: 213-221

[14] Brewer EW. 13 Proven Ways to Get Your Message Across: The Essential Reference for Teachers, Trainers, Presenters, and Speakers. Thousand Oaks, CA, USA: Corwin Press; 1997

[15] Gousseau M, Sommerfeld C, Gooi A. Tips for using mobile audience response systems in medical education. Adv Med Educ Pract 2016; 7: 647652

[16] Hur Y, Cho AR, Kim S. Exploring the possibility of one-on-one mentoring as an alternative to the current student support system in medical education. Korean J Med Educ 2018; 30: 119-130

[17] Tague NR. The Quality Toolbox. 2nd ed. Milwaukee, Wisc, USA: ASQ Quality Press; 2004
[18] Collective D-BR. Design-Based Research: An Emerging Paradigm for Educational Inquiry. Educational Researcher 2003; 32: 5-8

[19] Thoma B, Bandi V, Carey R et al. Developing a dashboard to meet Competence Committee needs: a design-based research project. Can Med Educ J 2020; 11: e16-e34

[20] Bingen HM, Steindal SA, Krumsvik RJ et al. Studying physiology within a flipped classroom: The importance of on-campus activities for nursing students' experiences of mastery. J Clin Nurs 2020. doi:10.1111/ jocn. 15308

[21] Kothiyal A, Murthy S. MEttLE: a modelling-based learning environment for undergraduate engineering estimation problem solving. Res Pract Technol Enhanc Learn 2018; 13: 17

[22] Chi MT, Wylie R. The ICAP framework: Linking cognitive engagement to active learning outcomes. Educational Psychologist 2014; 49: 219-243

[23] Romeike BFM, Fischer M. Buzz groups facilitate collaborative learning and improve histopathological competencies of students. Clin Neuropathol 2019; 38: 285-293

[24] Premkumar K, Coupal C. Rules of engagement-12 tips for successful use of "clickers" in the classroom. Med Teach 2008; 30: 146-149

[25] Farmer EA, Page G. A practical guide to assessing clinical decisionmaking skills using the key features approach. Med Educ 2005; 39 : 1188-1194

[26] Fischer MR, Kopp V, Holzer M et al. A modified electronic key feature examination for undergraduate medical students: validation threats and opportunities. Med Teach 2005; 27: 450-455

[27] Schmidmaier R, Eiber S, Ebersbach R et al. Learning the facts in medical school is not enough: which factors predict successful application of procedural knowledge in a laboratory setting? BMC Med Educ 2013; 13: 28

[28] Bonk C], Graham CE. The handbook of blended learning: global perspectives, local designs. 1. ed. San Francisco, CA, USA: Pfeiffer; 2006

[29] Bergmann J, Sams A. Flip your Classroom: reach every student in every class every day. 1. ed. International Scociety for Technology in Education; 2012 